\title{
PROCESSING OF NICKEL ALUMINIDES AND THEIR INDUSTRIAL APPLICATIONS
}

V. K. Sikka

Metals and Ceramics Division Oak Ridge National Laborator:

P.O. Box 2008

Oak Ridge, Tennessee 37831
J. T. Mavity and K. Anderson Precision Rolled Products, Inc. P.O. Box 60010

Reno, Nevada 89506

\section{ABSTRACT}

Ductile $\mathrm{Ni} 3 \mathrm{Al}$-based alloys offer unique properties. However, their use has been limited because information is lacking regarding their processing into various product forms. This paper describes the recent progress made toward melting, electroslag remelting, and the processing of large-scale ingots of one of the Ni3Al-based alloys. Microstructural data are presented after various homogenization treatments. Both as-cast and homogenized samples were subjected to hot-compression testing. The hotcompression data for the commercial-size ingot showed the same behavior as previously reported on the experimental heats. The status of industrial applications of nickel-aluminide alloys is also described.

\section{INTRODUCTION}

The ductile, Ni3Al-based, intermetallic alloys have been under development for only a few years [1,2]. Several applications have also been identified for them [3]. Furthermore, the patented alloy compositions based on $\mathrm{Ni3} A l$ have been licensed [4] for either their production or use to several industrial organizations. However, their applications have been sornewhat limited because processing methods, especially for the commercial-size production, are not fully developed. The purpose of this paper is to present the $\mathrm{Ni} 3 \mathrm{Al}$-based compositions of industrial interest, review the current processing 
status, present details of a recent joint study for the commercial production and processing of one of the alloys, discuss future plans, and give the status of various applications.

\section{ALLOY COMPOSITIONS}

Three compositions based on $\mathrm{Ni}_{3} \mathrm{Al}$ are currently considered $[5,6]$ to be useful for commercial applications. These are designated as IC-50, IC-218LZr, and IC-221M (Table 1). The IC refers to intermetallic compound.

\section{REVIEW OF PROCESSING STATUS}

Several factors that determine the processing response of an alloy include: ductility $(\geq 30 \%)$ of the cast structure at high temperatures and industrial strain rates $\left(1.67 \times 10^{-1} \mathrm{~s}^{-1}\right)$, strength of the cast structure at temperature, a temperature range for high ductility, absence of liquid formation in the processing temperature range, absence of environmental effects (oxidation) in the processing temperature range, and good intermediate temperature ductility $(\geq 10 \%$ ) to prevent cracking during cooling from hot processing temperatures. Based on the criteria above, the alloys in Table 1 are briefly described below:

IC-50

This alloy has limited hot ductility, low ductility in the intermediate temperature range $\left(600\right.$ to $\left.800^{\circ} \mathrm{C}\right)$ because of dynamic oxigen embrittlement $[2,6]$, and peak strength in the intermediate temperature range. These characteristics make the alloy only processable through near-net-shape processes, followed by cold working. The near-net-shape processes that have been used successfully for IC-50 include: the direct casting of bar from the liquid metal, the direct casting of sheet [6] from the liquid metal, the centrifugal casting of tube hollows, and electroslag castings. The hot working of the alloy is possible by enclosing the billet in a stainless steel can. This alloy can also be consolidated by powder 
metallurgy $[7,8]$. The fine grain, powder metallurgy microstructure showed superplastic behavior [9], which can be used for isothermal processing of near-net-shape parts.

\section{IC-218LZr}

- Compared to IC-50, IC-218LZr has high ductility at high temperatures and much lower susceptibility to dynamic oxygen embrittlement. This alloy contains 10 to $15 \mathrm{vol}$ fraction of the disordered $\gamma$-phase $(72 \mathrm{Ni}-5 \mathrm{Al}-23 \mathrm{Cr}$ at. \%) which increases with temperature. Based on these characteristics, this alloy is considered hot workable [10]. Details of a recent joint study for commercial production and processing of this alloy are described in the next section.

\section{IC-221M}

This alloy is designed [5] to obtain increased room-temperature strength in the ascast condition. The alloy is also designed to be castable with minimum casting defects such as porosity. For improved castability, this alloy contains $1.7 \mathrm{wt} \% \mathrm{Zr}$. This level of zirconium can result in the formation of the eutectic, Ni5 $\mathrm{Zr}$. This eutectic melts at $1170^{\circ} \mathrm{C}$ and, thus, limits the alloy's hot workability. The alloy can be cold worked with intermediate anneals at $1100^{\circ} \mathrm{C}$. The IC-221M alloy has been precision cast into complex shapes such as turbocharger rotors.

\section{COMMERCIAL PRODUCTION AND PROCESSING OF}

\section{ALLOY IC-218LZr}

\section{MELTING}

A $2465-\mathrm{kg}$ heat of IC-218LZr alloy was vacuum-induction melted (VIM) at Precision Rolled Products (Florham Park, New Jersey). The heat was cast into a 330-mmdiam mold to prepare an electrode for secondary melting. The chemical analysis of this VIM heat is compared with the target composition in Table 2. The photogiaph of the 
electrode is shown in Fig. 1. A section from this electrode was cut and macroetched

(Fig. 2). The structure of the VIM electrode is typical of a statically cast and solidifying ingot. The 330-mm-diam electrode was electroslag remelted (ESR) into a 403-mm-diam ingot (Fig. 3). Since this was the first ESR process of this alloy, the bottom $178 \mathrm{~mm}$ of the ingot were taken up in optimizing the melting parameters, which resulted in a rippled surface. The remaining $2.6 \mathrm{~m}$ of the ingot length had a smooth surface finish, very similar to that observed for many of the nickel-based superalloys. This heat and the ingot are the first of this size to be prepared commercially.

Several slices were cut from the 403-mm-diam ESR ingot. The macroetching of these slices (Fig. 4) showed very fine grain structure near the ingot surface and coarser structure near the center. No columnar grains were observed, and the ESR grain structure, overall, was much finer than the VIM electrode structure. The higher magnification photographs of the macroetched section of the ESR ingot (Fig. 5) showed evidence of cracks starting at the center and propagating radially. The cracks showed no significant preference for grain boundaries. They were both transgranular and intergranular. The exact reason for the cracks is not understood. Hewever, it is speculated that the large thermal stresses from cooling the ingot through the low-ductility temperature range (600 to $800^{\circ} \mathrm{C}$ ) is responsible for these cracks. A slow cooling step followed by a stress-relief treatment are expected to minimize the problem.

\section{HOMOGENIZATION TREATMENT}

A $1204^{\circ} \mathrm{C}$ treatment in. air for times ranging from 8 to $208 \mathrm{~h}$ was used for homogenization of the ingot microstructure. Microstructures from this study are shown in Figs. 6(a) through 6(f). The as-cast microstructure consisted of fine $\gamma^{\prime}(75 \mathrm{Ni}-16 \mathrm{Al}$ $8 \mathrm{Cr}$ at. \%) and islands of $\gamma$ and $\gamma^{\prime}$. The time at temperature resulted in a significant change in the island microstructure. In fact, the islands were replaced by coarse $\gamma$-phase particles. These particles were present in both the matrix and at the grain boundaries. Room- 
temperature microhardness of $\gamma$ and $\gamma^{\prime}$ phases were measured to be 300 and $293 \mathrm{dph}$, respectively, for a specimen exposed at $1204^{\circ} \mathrm{C}$ for $208 \mathrm{~h}$. Although room-temperature hardness was the same for the $\gamma$ and $\gamma^{\prime}$ phases, the $\gamma$-phase is known to be much weaker at high temperatures than the $\gamma^{\prime}$-phase. Thus, the specimens containing coarse $\gamma$-phase particles are expected to be more hot workable. Hot-hardness data of such phases will be - extremely useful to confirm this point.

\section{HOT-UPSET FORGING}

Cylindrical specimens of $38-\mathrm{mm}$ diam and $64-\mathrm{mm}$ length were machined from the bottom slice of the ingot. Specimens taken parallel to the radius of the slice are designated longitudinal, and those parallel to the thickness of the disk are designated as transverse. Figure 7 shows the macroetched cylinders from the outer edge and mid radius locations. In order to minimize oxidation and reduce friction, the cylinders were given two coats of boron nitride prior to heat treating or upset forging. All of the specimens were forged in air at $1200^{\circ} \mathrm{C}$ using a 500 -ton press with die platens at room temperature. The results of this study are shown in Figs. 8 and 9. The following observations are possible from these figures:

1. The longitudinal orientation, which will be the case in real practice, performed much better than the transverse orientation.

2. The as-cast (unexposed) specimens performed better during hot-upset forging than the specimens exposed to $1200^{\circ} \mathrm{C}$, although the microstructure of the specimens appeared to be more hot workable. It is believed that two factors may be causing the poor performance of the specimens exposed to $1200^{\circ} \mathrm{C}$. The first factor may be the oxidation of the grain boundaries near the outer surface from the long-term exposure at $1200^{\circ} \mathrm{C}$. The second factor may be the potential for the liquid phase formation from the long-term exposure. Photomicrographs (Fig. 10) of a cylinder exposed for $64 \mathrm{~h}$ at $1200^{\circ} \mathrm{C}$ show evidence for oxidation along the grain boundaries and liquid phase 
formation. The oxidized grain boundaries extend $0.38 \mathrm{~mm}$ into the specimen. The isolated, oxidized regions extend as far as $0.76 \mathrm{~mm}$. No evidence of liquid-phase formation was observed in the metallographically polished cylinders even after a 64-h exposure at $1200^{\circ} \mathrm{C}$. However, some evidence of fine-granular phase was observed on the outer surface after exposure. This granular phase may be an indication of some liquid formation near the surface. One cylinder that had been exposed for $64 \mathrm{~h}$ at $1200^{\circ} \mathrm{C}$ was machined to remove $1.25 \mathrm{~mm}$ from the surface prior to testing. This cylinder showed no surface cracks after a $25 \%$ reduction. However, some cracking was observed after a $50 \%$ reduction. Compared to the $64-\mathrm{h}$ exposed specimen in Fig. 9(b), the machined cylinder showed significant improvement in response to hot forging. The hot-upset forging response of the specimens from the 403-mm-diam ingot is compared with the results on the experimental heats $[10,11]$ in Fig. 11. The experimental heats were also tested in the cast condition. In general, the specimens from the $403-\mathrm{mm}$-diam ingot showed the hot forgeability response similar to the experimental heats.

\section{FUTURE PLANS}

The hot-upset-forging results and Gleeble test data in progress on the specimens from the ingot will be used to optimize the homogenization treatments and the hot-working conditions to be used for the 403 -mm-diam ingot. The current plan is to hot-rotary forge this ingot in the rotary forging machine at Carpenter Technology Corporation (Reading, Pennsylvania). The ingot diameter will be reduced to $330 \mathrm{~mm}$ (34\% reduction in area) and, if successful, will be further reduced in the same rotary forge machine to $100 \mathrm{~mm}$ (94\% reduction in area). 


\section{MICROSTRUCTURE OF SMALL HEAT PROCESSED COMMERCIALLY}

A $45-\mathrm{kg}$ VIM heat of IC-218LZr was processed by hot extrusion at $1100^{\circ} \mathrm{C}$ in a steel can. The extrusion ratio was $36: 1$. Some portions of this bar were subsequently cold swaged $58 \%$ and annealed at $1100^{\circ} \mathrm{C}$. The microstructure of the as-extruded and subsequently cold-processed bars is compared in Fig. 12. These microstructures show that the hot processing of the alloy is feasible and that it produces uniform, equiaxed microstructure.

\section{STATUS OF VARIOUS APPLICATIONS}

The Ni3Al-based alloys have a potential for many applications. Each of the applications is identified, and its status and issues for full use are described.

\section{AUTOMOTIVE}

Turbocharger rotors of nickel aluminide in diesel trucks are the near-term application. Nickel aluminide will replace $\mathrm{IN}-713 \mathrm{C}$, and major benefits include the improved fatigue life and potential for lower cost. Significant commercial effort by Cummins Engine Company (Columbus, Indiana) and Precision Castparts Corporation (Portland, Oregon) has been devoted to casting the turbocharger rotors and fatigue test bars. The turbocharger rotors have gone through significant evaluation, and the test bars have been tensile and fatigue tested [12] at the Oak Ridge National Laboratory. The application is near implementation. Remaining issues include: (1) further control of casting porosity and grain size and (2) additional fatigue data.

The other application of nickel aluminide in the automotive industry is the dies for hot pressing the Fe-B-Nd magnetic powders. The nickel aluminides are the only materials that are chemically compatible, possess sufficient strength at the hot-pressing temperature, and have the oxidation resistance for this application. The dies of nickel aluminide are currently in use for this application. Both applications discussed above use alloy IC-221M. 


\section{METAL PROCESSING}

The high-temperature oxidation resistance $\left(\leq 1100^{\circ} \mathrm{C}\right)$ and the strength make nickel aluminide ideal as die material for isothermal forging. Some use of nickel aluminide for this application is already in progress. The commercial production of high-quality die castings is still an issue for wider use of nickel aluminides for this application. Alloys IC-221 and IC-218LZr are being tested for this application.

The rollers for steel-slab-heating furnaces are a potential application. The hightemperature strength and oxidation resistance of nickel aluminides can produce significant savings in energy costs by not requiring water cooling and in material costs by extending the life four to six times over the current material in use. Some of the rollers are currently in test. A setup for commercial melting, centrifugal casting, and welding is needed to supply the quality product necessary for this application. The IC-221M alloy is the material of choice for this application.

\section{GLASS PROCESSING}

The oxidation resistance, high-temperature streng $h$, and high fatigue life make nickel-aluminide alloys attractive for glass processing. Severa. crials are currently under way. Major issues for this application include: (1) thermal fatigue data, (2) machining data, (3) weld repair of used parts, (4) grain size control of part interior, and (5) near surface. The IC-221M is the primary alloy for this application.

\section{HYDROTURBINES}

Nickel aluminides offer better cavitation erosion resistance of any of the currently used materials. This property makes them ideal for either repair of current hydroturbine rotors or even replacement of the entire units with these alloys. The issues for this application require the development of methods for repairing the turbines currently in use 
and casting of new turbine rotors. The savings expected from this application of nickel aluminides can be quite substantial. Alloy IC-50 is recommended for this application.

\section{FEED WATER PUMPS}

- The cavitation erosion resistance of nickel aluminides makes them extremely attractive for feed water pumps. The issues for this application are similar to those listed above for hydroturbines. Alloy IC-50 is recommended for this application.

\section{CHEMICAL PROCESSING}

Nickel aluminide offers a favorable combination of strength and corrosion resistance for use as extruder stems for the processing of artificial rubber. This application requires the hot-workable alloy, ease of machining, and grinding. Alloy IC-218LZr will be used for this application.

\section{BINDER FOR CERAMICS}

Nickel aluminide has potential for replacement of cobalt in tungsten-carbide systems. The nickei-aluminide-bonded tungsten carbide has better low- and hightemperature strength and cutting properties than cobalt-bonded tungsten carbide. Work is needed to further optimize the selection of the nickel-aluminide alloy and its content to be added. Wear and cutting properties of nickel-aluminide-bonded tungsten carbide need to be determined. Both IC-50 and IC-2181, $\mathrm{Zr}$ are being tested as binders.

\section{ROLLER BEARINGS}

The wear resistance of nickel aluminide increases by a factor of over 1000 from room temperature to $650^{\circ} \mathrm{C}$. This property makes it unique for high-temperature bearing material. Work is needed to increase the wear resistance at room temperature through cold working. Roller contact fatigue tests at :oom temperature and high temperatures need to be 
conducted. This application is considered to be long term. Alloy IC-218LZr will be tested for this application.

\section{SUMMARY AND CONCLUSIONS}

Three alloys being developed for commercialization, based on $\mathrm{Ni} 3 \mathrm{Al}$, were

described. A brief description of the processing response of each alloy was given based on their general characteristics. A joint effort with industry in commercial melting and processing of one of the alloys (IC-218LZr) was described in detail. The first large-scale melting of a $2465-\mathrm{kg}$ heat by the VIM process, followed by the ESR process, was also described. The 403-mm-diam ESR ingot showed internal cracking, the cause for which remains unexplained at the present time. The hot-working response from the sound sections of the ingot showed that up to $50 \%$ hot reductions can be obtained at $1200^{\circ} \mathrm{C}$. High-temperature homogenization produced changes in the microstructure, which appeared to be more hot workable. However, the unexposed specimens performed better during hot-upset experiments. Near-surface oxidation of the grain boundaries was considered responsible for the surface cracking of the pre-exposed specimens during hot-upset forging. This concept was confirmed for a pre-exposed specimen for which $1.25 \mathrm{~mm}$ of the surface was machined prior to testing. The hot-working response of the 403-mm-diam ingot was similar to the response of the laboratory-size heats tested previously. The microstructure of a $45-\mathrm{kg}$ heat of IC-218LZr processed by hot extrusion and, subsequently, by cold working showed that a uniform equiaxed fine-grain microstructure can be produced in this alloy.

Specific conclusions from this work are:

1. The IC-218LZr alloy can be commercially melted into 403-mm-diam ingots. The melting parameters are similar to commercial nickel-based alloys. Internal cracking observed in this ingot is unexplained but can most likely be avoided through process optimization. 
2. Hot-upset-forging tests show the hot-forging response of the 403-mm-diam ingot is similar to that observed for the experimental heats.

\section{ACKNOWLEDGMENTS}

The authors thank Steve Mapes and Dick Cook at Precision Rolled Products (Florham Park, New Jersey) for melting and heat-treatment response, respectively; E. C. Hatfield and K. S. Blakely for hot-compression testing; J. R. Weir, Jr. and M. L. Santella for paper review; and M. L. Atchley for typing the manuscript.

This work was sponsored by the U.S. Department of Energy, Assistant Secretary for Conservation and Renewable Energy, Office of Industrial Technologies, Advanced Industrial Concepts (AIC) Materials Program under contract DE-AC05-84OR21400 with Martin Marietta Energy Systems, Inc.

\section{REFERENCES}

1. C. T. Liu, C. L. White, and J. A. Horton, Acta Metall., 33 (1985) 213-229.

2. C. T. Liu and V. K. Sikka, J. Met., 38(5) (May 1986) 19-21.

3. Vinod K. Sikka, "Development of Nickel and Iron Aluminides and Their Applications," 30th Annual CIM Conference of Metallurgists International Symposium on Advances in Gas Turbine Engine Materials, Ottawa, Ontario, Canada, August 1820,1991 (in press).

4. V. K. Sikka, High Temperature Aluminides \& Intermetallics, The Minerals, Metals \& Materials Society, Pennsylvania, 1990, p. 505.

5. C. T. Liu, V. K. Sikka, J. A. Horton, and E. H. Lee, Alloy Development and Mechanical Properties of Nickel Aluminide Ni3Al Alloys, ORNL-6483, Martin Marietta Energy Systems, Inc., Oak Ridge National Lab., August 1988.

6. V. K. Sikka, Materials and Manufacturing Processes, 4(1) (1989) 1-24. 
7. V. K. Sikka and E. A. Loria, Nickel Metallurgy, Vol. II, Industrial Applications of Nickel, Canadian Institute of Mining and Metallurgy, Montreal, 1986, p. 293.

8. V. K. Sikka, Modern Developments in Powder Metallırgy - Vols. 18-21, Metal Powder Industries Federation, New Jersey, 1988, p. 543.

9. V. K. Sikka, Interdisciplinary Issues in Materials Processing and Manufacturing, Volume 2, ASME, New York, 1988, p. 451.

10. Vinod K. Sikka, Mat. Res. Soc. Symp. Proc., 133 (1989) 487-492.

11. V. K. Sikka, Advanced Materials and Processing Techniques for Structural Applications, AsM, Ohio, 1987, p. 295.

12. Brian Gieseke and Vinod K. Sikka, "The Effect of Casting Temperature on the Fatigue Properties of Cast Nickel Aluminide Alloys," International Conference on High-Temperature Aluminides \& Intermetallics, San Diego, California, September 1619, 1991 (submitted for publication).

\section{DISCLAIMER}

This report was prepared as an account of work sponsored by an agency of the United States Government. Neither the United States Government nor any agency thereof, nor any of their bility for the anes any warranty, express or implied, or assumes any legal liability or responsibility for the accurac $y$, completeness, or usefulness of any information, apparatus, product, or ence herein to any ence herein to any specific commercial product, process, or service by trade name, trademark, mendation, or necessarily constitute or imply its endorsement, recommendation, or favoring by the United States Government or any agency thereof. The views United States Government or any herein do not necessarily state or reflect those of the 
Table 1. Compositions of ductile, $\mathrm{Ni} 3 \mathrm{Al}$-based alloys

\begin{tabular}{lccc}
\hline & \multicolumn{3}{c}{ Alloy designation (wt \%) } \\
\cline { 2 - 4 } Element & IC-50 & IC-218LZr & IC-221M \\
\hline $\mathrm{Al}$ & 11.3 & 8.69 & 7.98 \\
$\mathrm{Cr}$ & -- & 8.08 & 7.74 \\
$\mathrm{~B}$ & 0.02 & 0.02 & 0.008 \\
$\mathrm{Zr}$ & 0.6 & 0.20 & 1.70 \\
$\mathrm{Mo}$ & -- & -- & 1.43 \\
$\mathrm{Ni}$ & 88.08 & 83.01 & 81.15 \\
\hline
\end{tabular}


Table 2. Comparison of target chemistry and check analysis of 330-mm-diam vacuum-induction-melted

IC-218LZr electrode

\begin{tabular}{|c|c|c|}
\hline \multirow{2}{*}{ Element } & \multicolumn{2}{|c|}{ Weight percent } \\
\hline & Target & Check analysis \\
\hline $\mathrm{Al}$ & 8.69 & 8.78 \\
\hline $\mathrm{Cr}$ & 8.08 & 8.09 \\
\hline B & 0.02 & $a$ \\
\hline $\mathrm{Zr}$ & 0.20 & 0.23 \\
\hline $\mathrm{Ni}$ & 83.01 & 82.60 \\
\hline Co & -- & 0.01 \\
\hline Mn & -- & 0.03 \\
\hline $\mathrm{Fe}$ & -- & 0.13 \\
\hline $\mathrm{Cu}$ & -- & 0.02 \\
\hline $\mathrm{Si}$ & -- & 0.06 \\
\hline $\mathrm{S}$ & -- & 0.0004 \\
\hline $\mathrm{Cb}$ & -- & 0.02 \\
\hline Mo & -- & 0.01 \\
\hline $\mathrm{Ti}$ & -- & 0.01 \\
\hline $\mathrm{C}$ & -- & 0.0075 \\
\hline $\mathrm{O}$ & -- & 0.0010 \\
\hline $\mathrm{N}$ & -- & 0.0002 \\
\hline
\end{tabular}

$a_{\text {Not analyzed. }}$ 


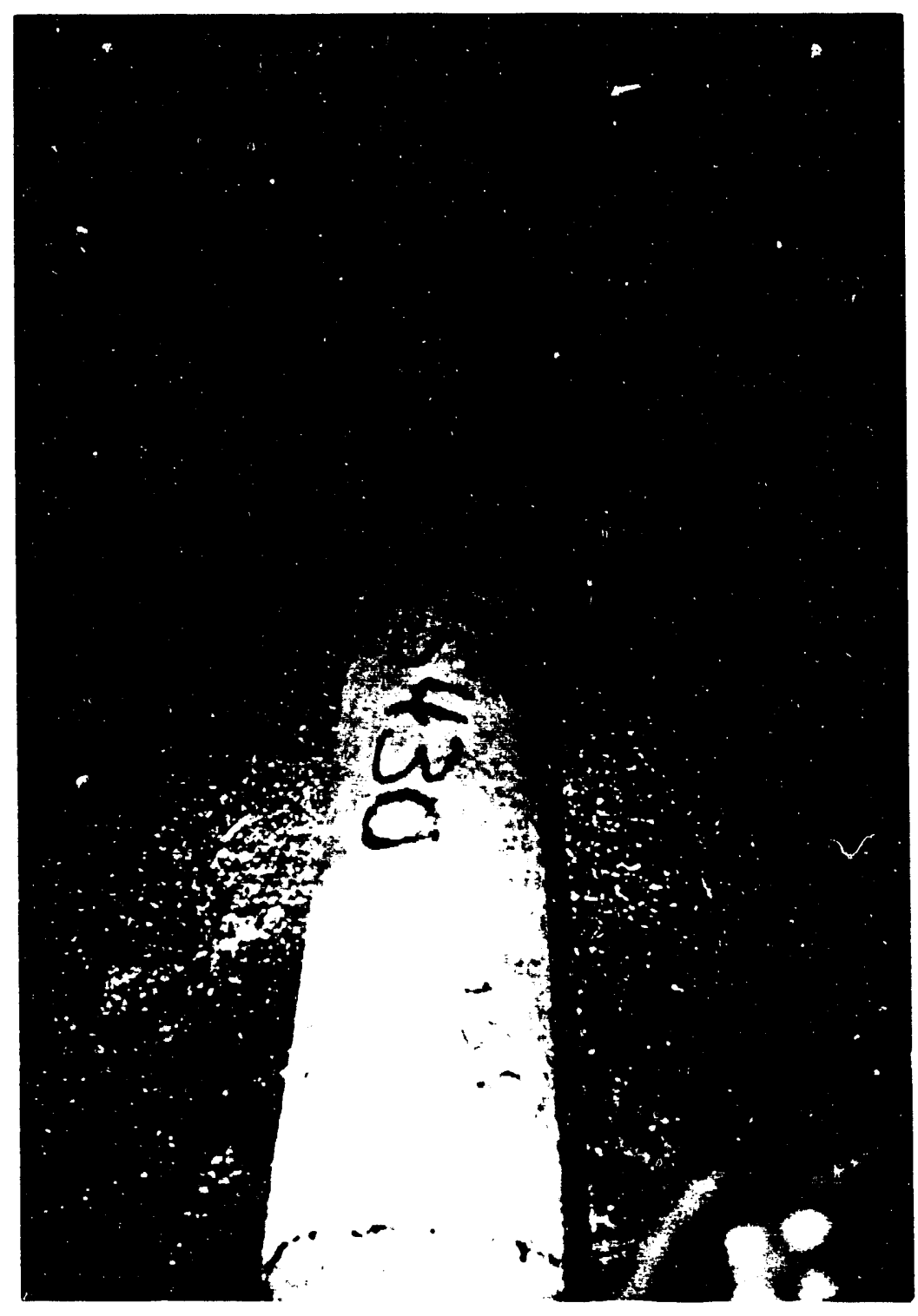

Fig. 1. A 33()-mm-diam, vacuum-induction-melted IC-218LZr electrode weighing $2465 \mathrm{~kg}$ prepared at Precision Rolled Products (Florham Park, New Jersey). 


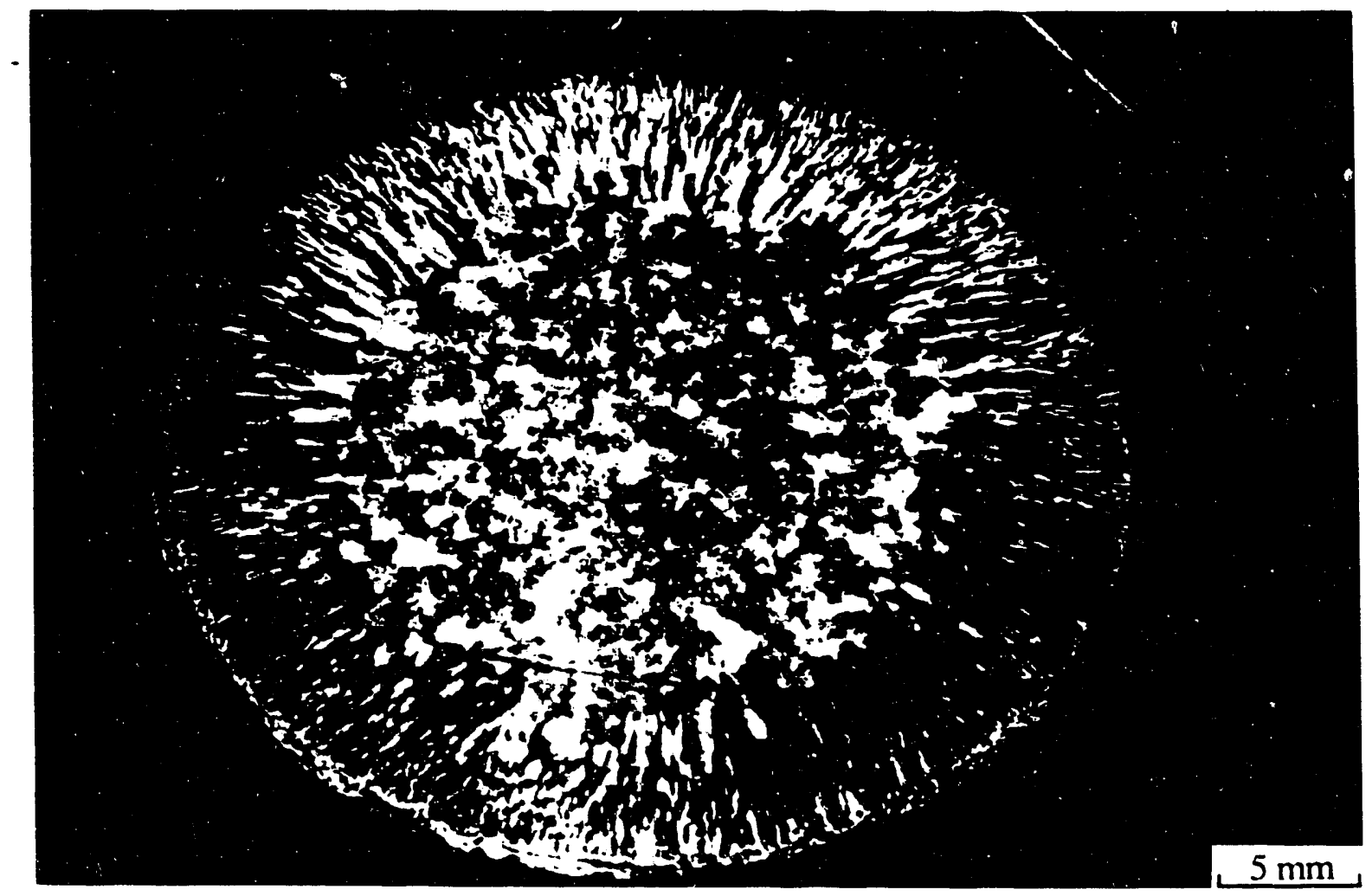

Fig. 2. Macroetched cross section of a 330-mm-diam, vacuum-induction-melted electrode of IC-218LZr prepared at Precision Rolled Products (Florham Park, New Jersey). 


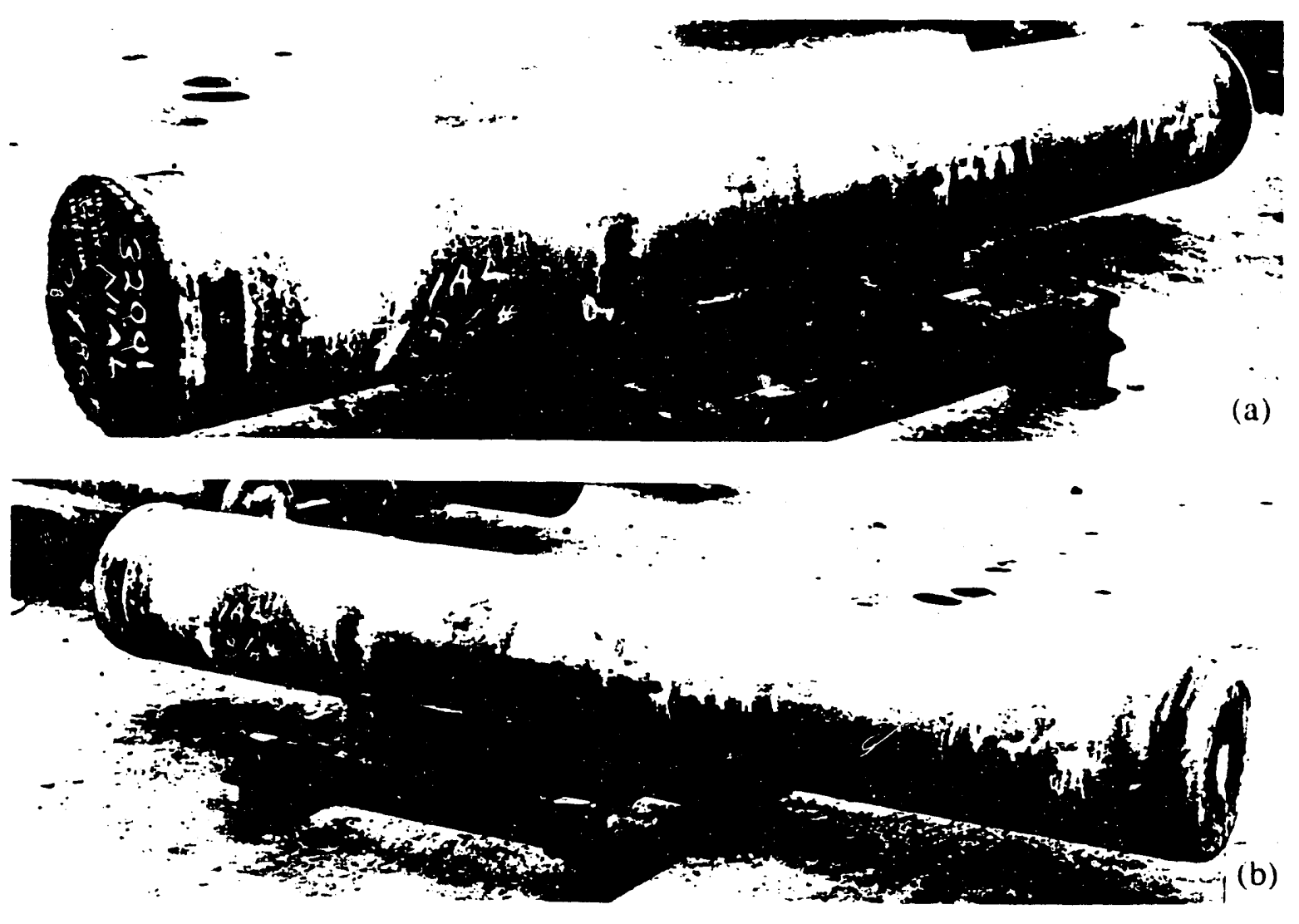

Fig. 3. A 403-mm-diam by 2.7 -m-long, electroslag-remelted ingot of IC-218LZr prepared at Precision Rolled Products (Florham Park, New Jersey: (a) starter plate and (b) ingot top. 


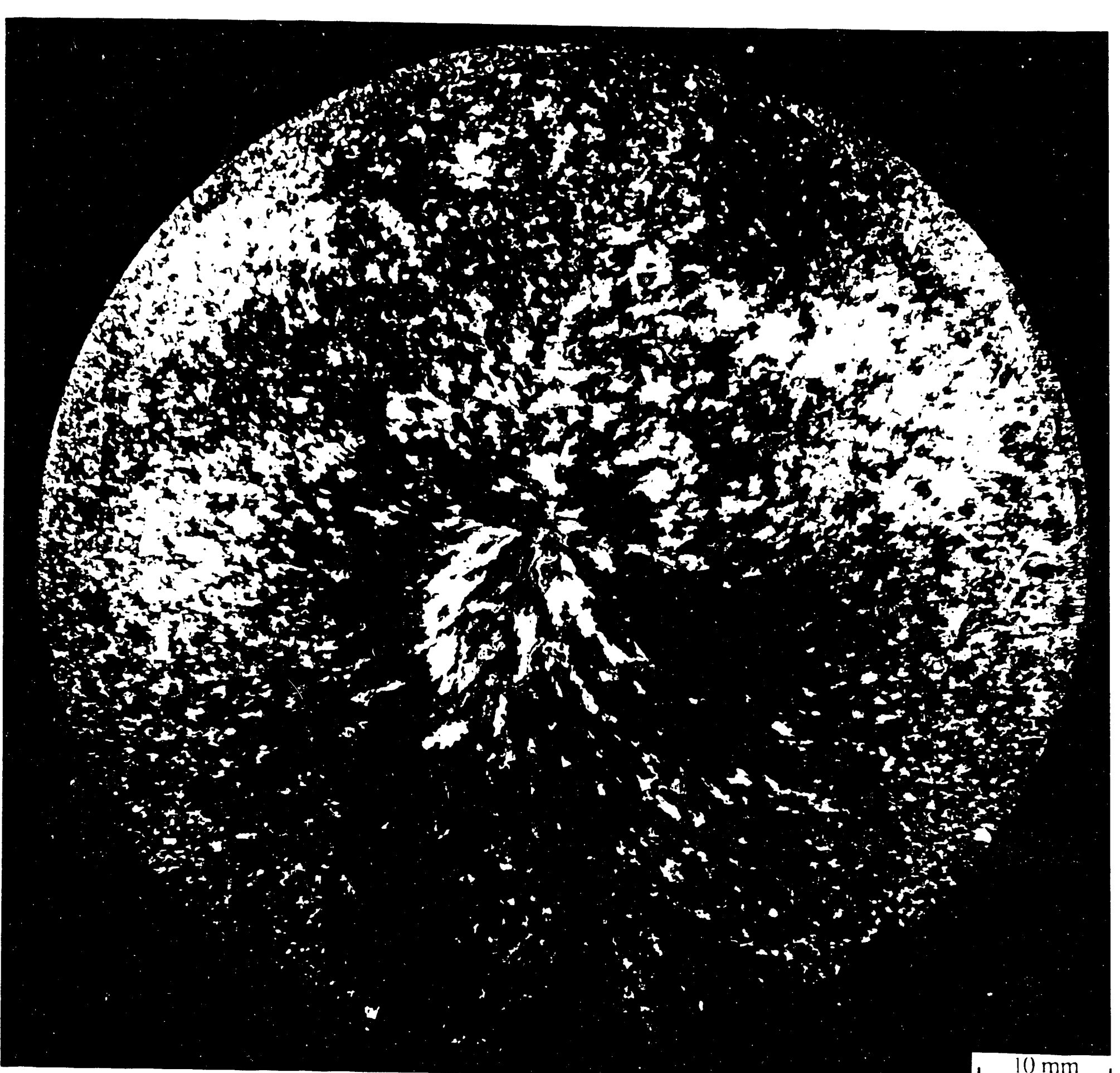

Fig. 4. Macroetched cross-section of a 4(03-mm-diam. electroslag-remelted IC-218LZr ingot. 


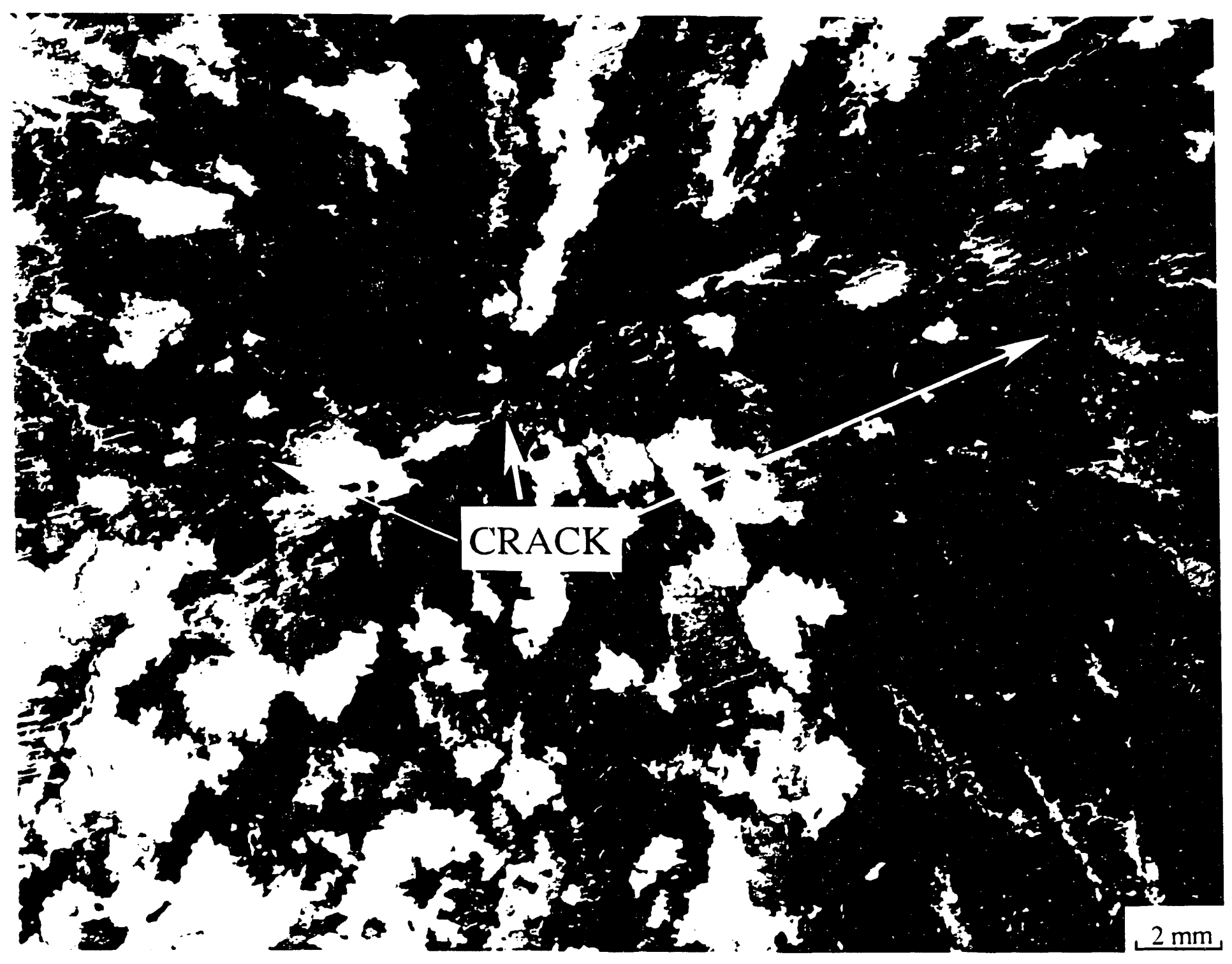

Fig. 5. Higher-magnification photograph of a macroetched section of a 403-mmdiam, electroslag-remelted ingot of IC-218LZr. Note the cracks. 

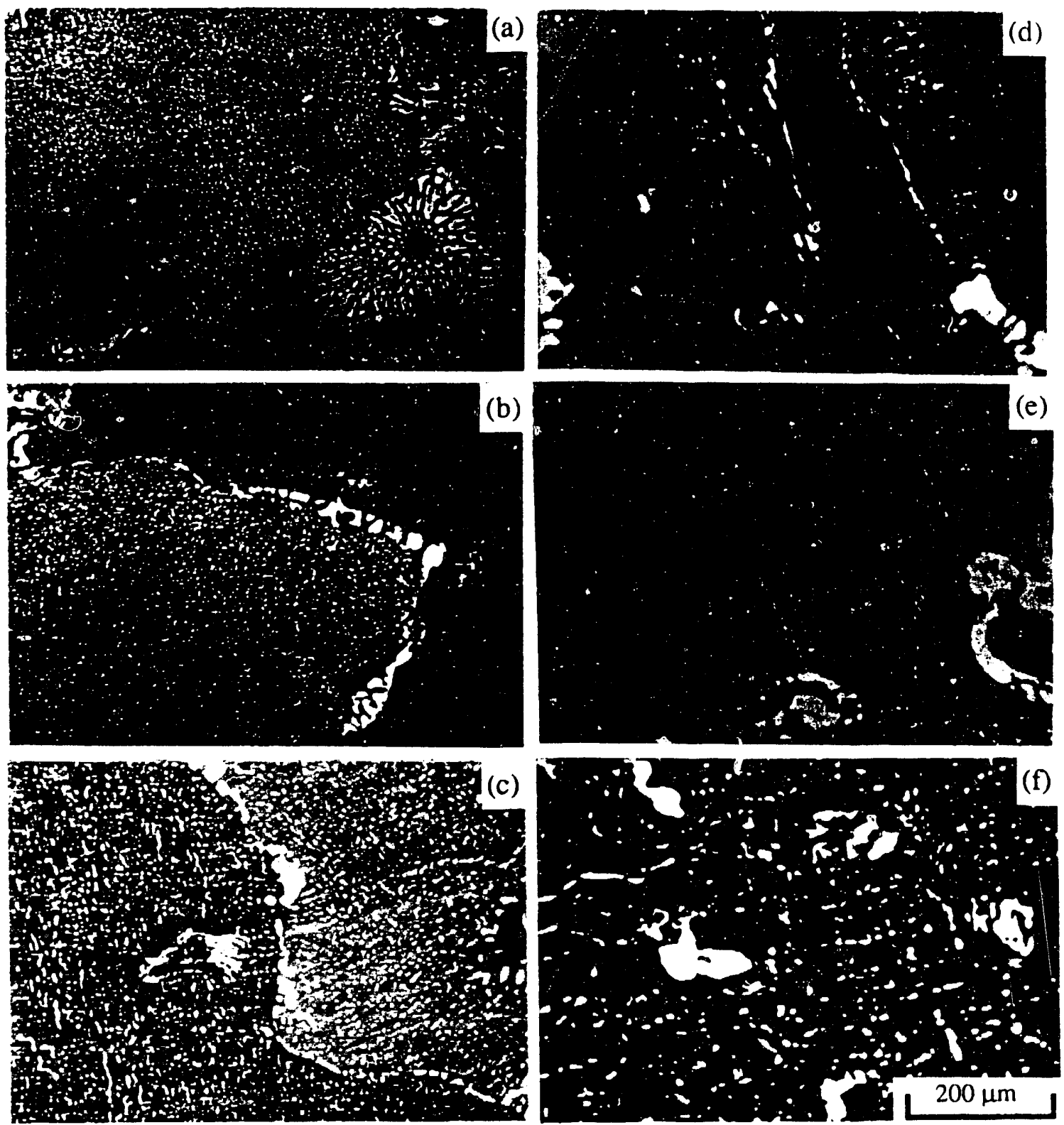

Fig. 6. Optical photomicrographs showing the change in microstructure by thermal exposure at $1204^{\circ} \mathrm{C}$ as a function of time for samples taken from a $4(03$-mm-diam, electroslag-remelted ingot of IC-218LZr: (a) as cast, (b) $8 \mathrm{~h}$, (c) $24 \mathrm{~h}$, (d) $64 \mathrm{~h}$, (e) $100 \mathrm{~h}$, and (f) $208 \mathrm{~h}$. 

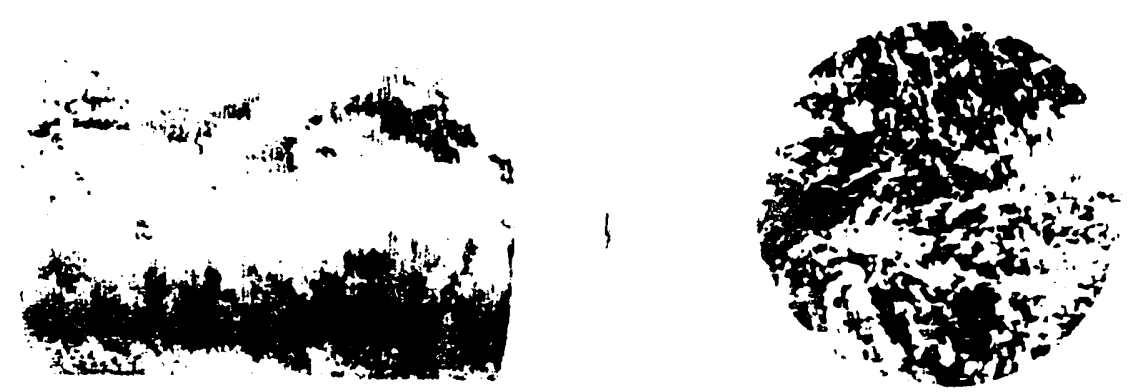

(a)

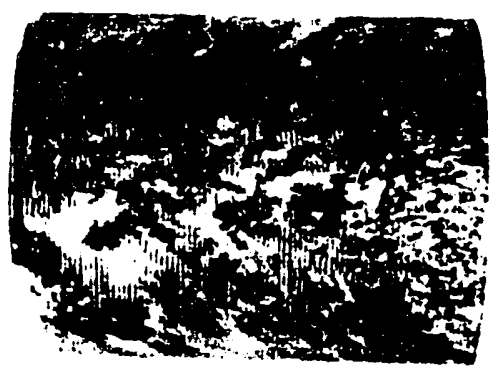

(b)

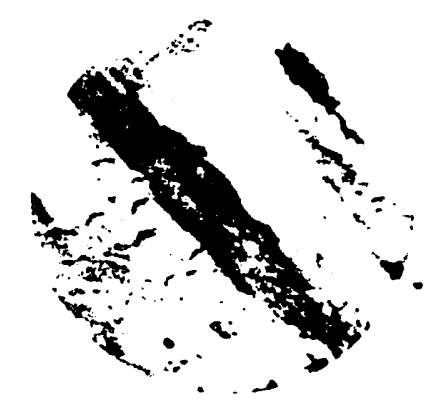

Fig. 7. Macroetched cylinders used for hot-upset forging. The cylinders were machined from a bottom section of the 403-mm-diam, electroslag-remelted ingot of IC-218LZr. The cylinder orientation is perpendicular to the ingot axis: (a) near-edge and (b) mid-radius. 


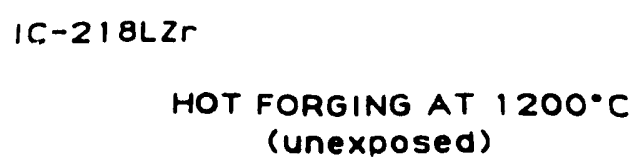

\section{LONGITUDINAL}

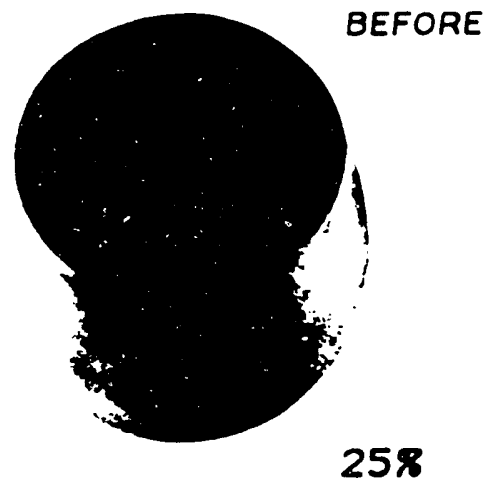

258

(a)

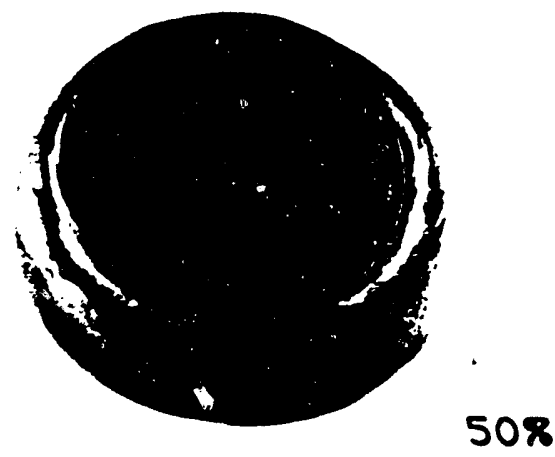

$1 C-218 L Z r$

HOT FORGING AT $1200^{\circ} \mathrm{C}$

(exposed $64 \mathrm{~h} / 1200^{\circ} \mathrm{C}$ )

\section{LONGITUDINAL}
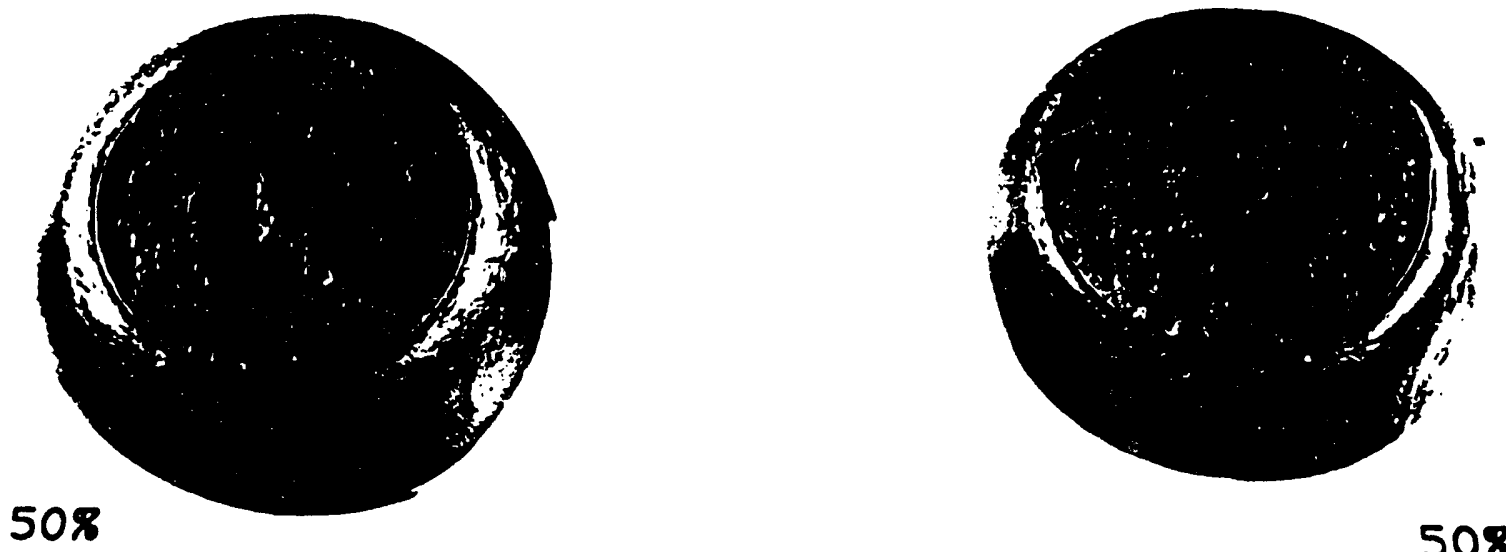

508

(b)

Fig. 8. Longitudinal cylinders after hot-upset forging at $1200^{\circ} \mathrm{C}$ : (a) no homogenization and tested and (b) homogenized for $64 \mathrm{~h}$ at $1200^{\circ} \mathrm{C}$ and tested. Note that the unexposed specimens look very good after both 25 and $50 \%$ reduction. One of the two exposed samples showed a few cracks after $50 \%$ reduction. 
HOT FORGING AT $1200^{\circ} \mathrm{C}$

(exposed $16 \mathrm{~h} / 1200^{\circ} \mathrm{C}$ )

TRANS VERSE
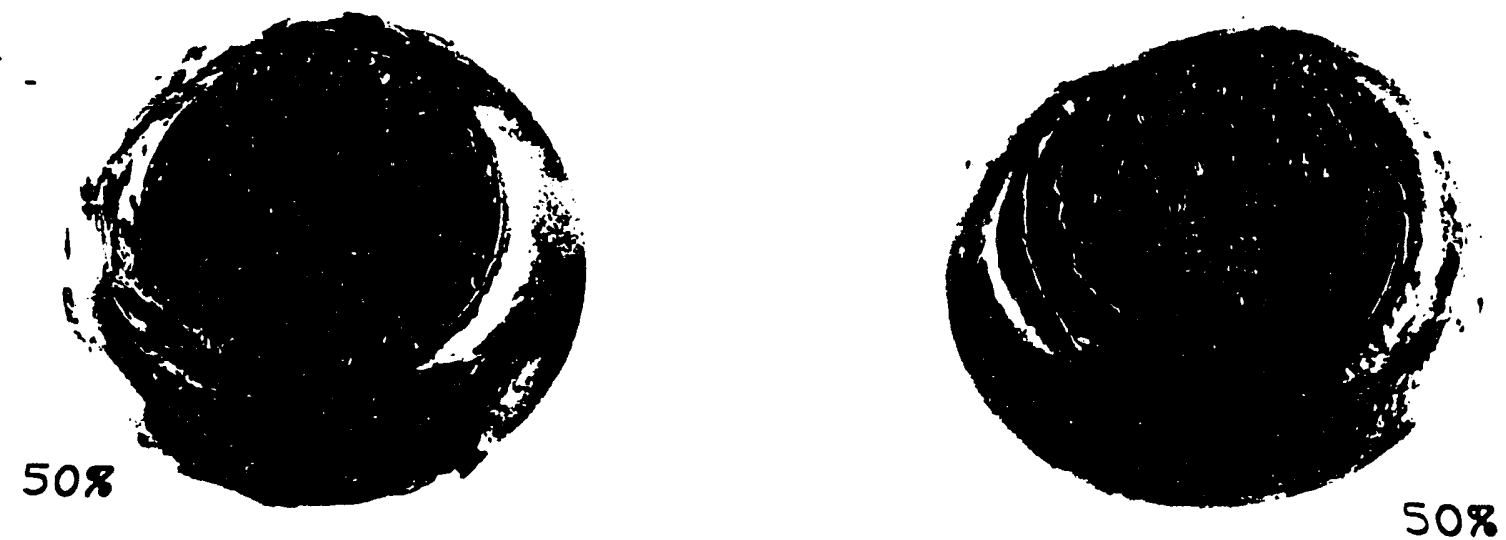

(a)

$1 C-218 L Z r$

HOT FORGING AT $1200^{\circ} \mathrm{C}$
(expOSEA $\left.64 \mathrm{H} / 1200^{\circ} \mathrm{C}\right)$

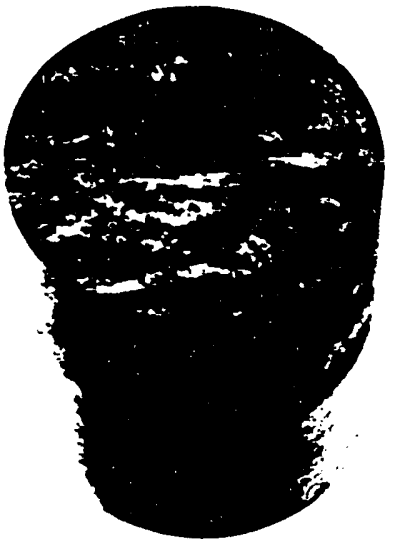

TRANSVERSE

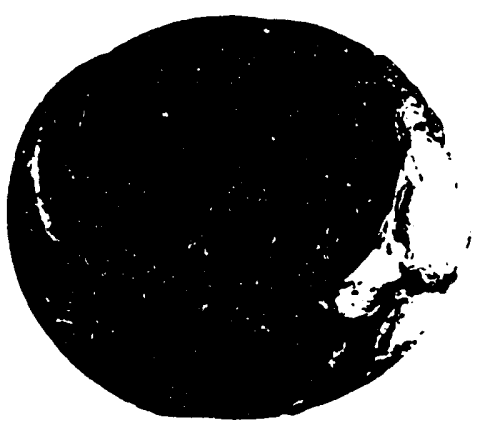

BEFORE

(b)

Fig. 9. Transverse cylinders after hot-upset forging at $1200^{\circ} \mathrm{C}$ : (a) exposed for $16 \mathrm{~h}$ at $1200^{\circ} \mathrm{C}$ and tested and (b) exposed for $64 \mathrm{~h}$ at $1200^{\circ} \mathrm{C}$ and tested. The starting cylinder for the specimen in (b) was shorter than (a). Note that this orientation is worse than the longitudinal orientation and that a $64-h$ exposure is worse than a 16 - $h$ exposure. 


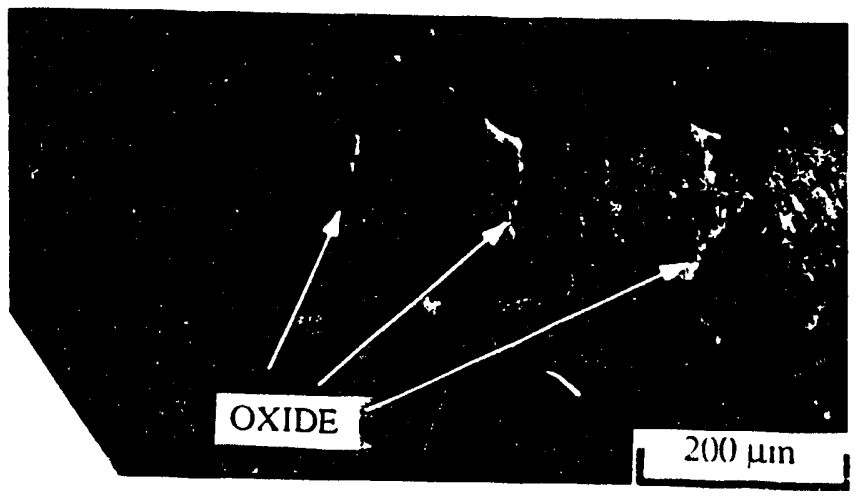

Fig. 10. Cylincier edge of a 403-mmdiam IC-218LZr ingot exposed in air at $1200^{\circ} \mathrm{C}$ for $64 \mathrm{~h}$. 


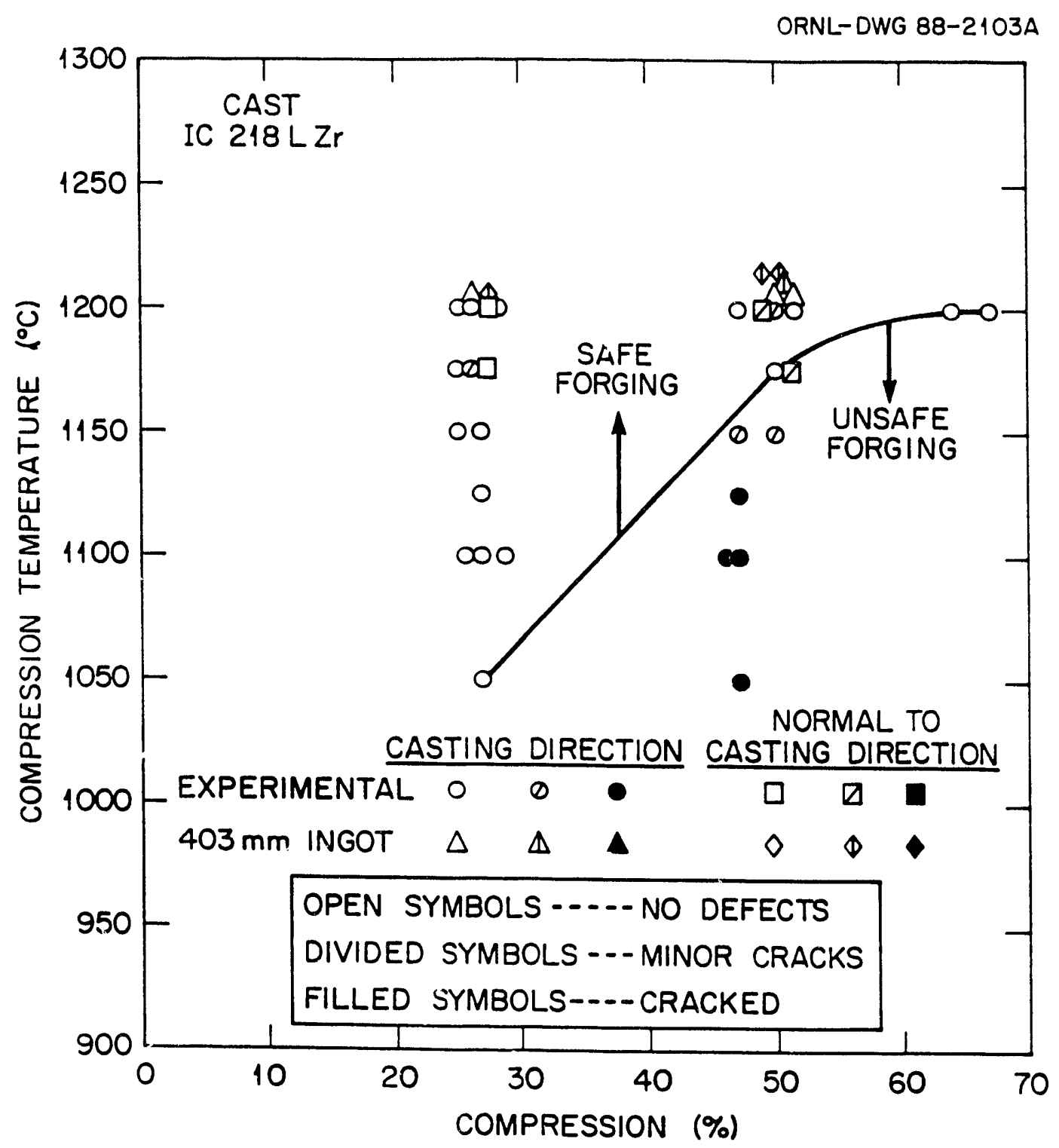

Fig. 11. Comparison of hot-compression response of experimental heat and $403-\mathrm{mm}$-diam ingot of IC-218LZI. 

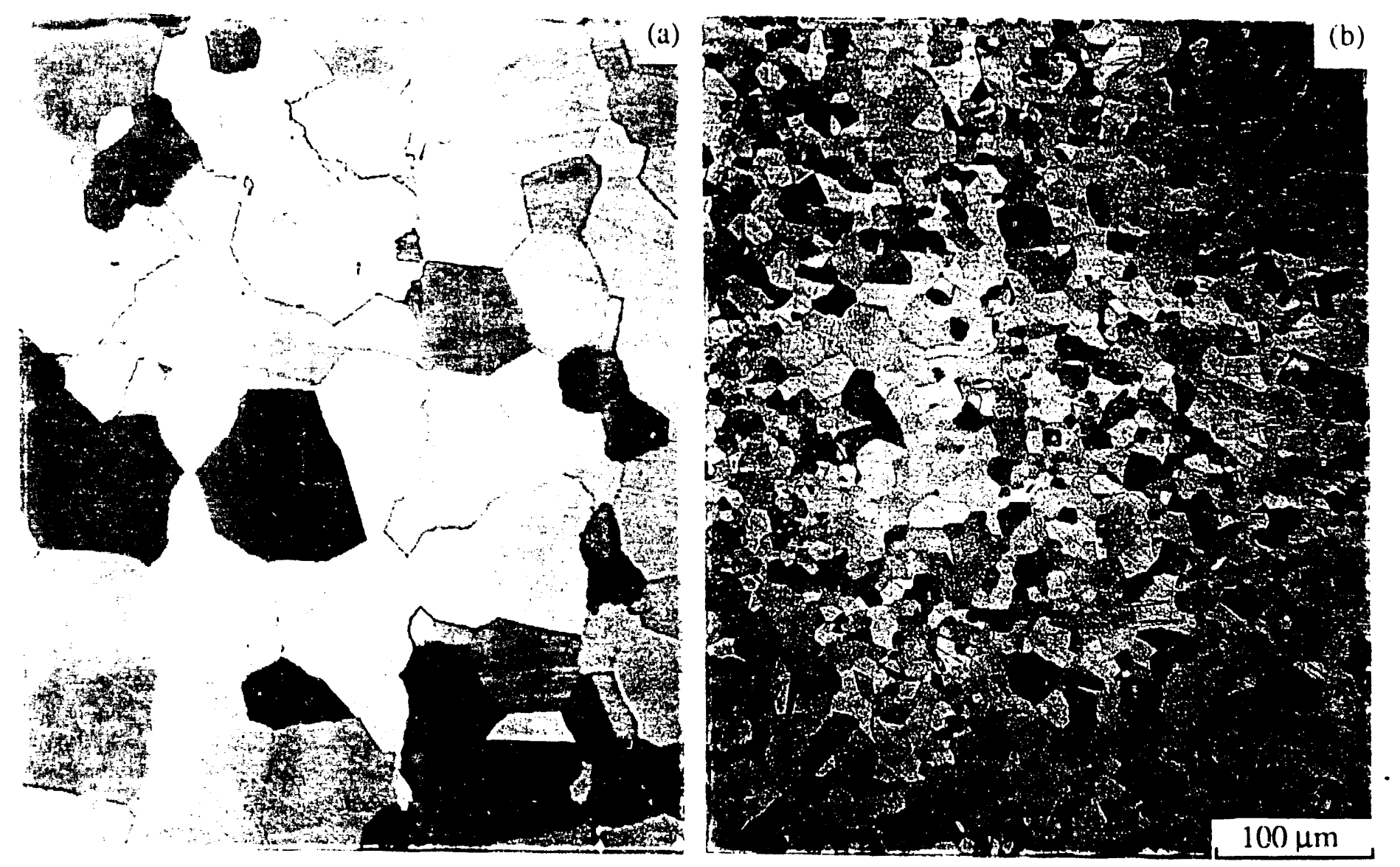

Fig. 12. IC-218LZr ingot: (a) as-extruded condition and (b) cold worked $58 \%$ and annealed at $1100^{\circ} \mathrm{C}$ for $1 \mathrm{~h}$. 

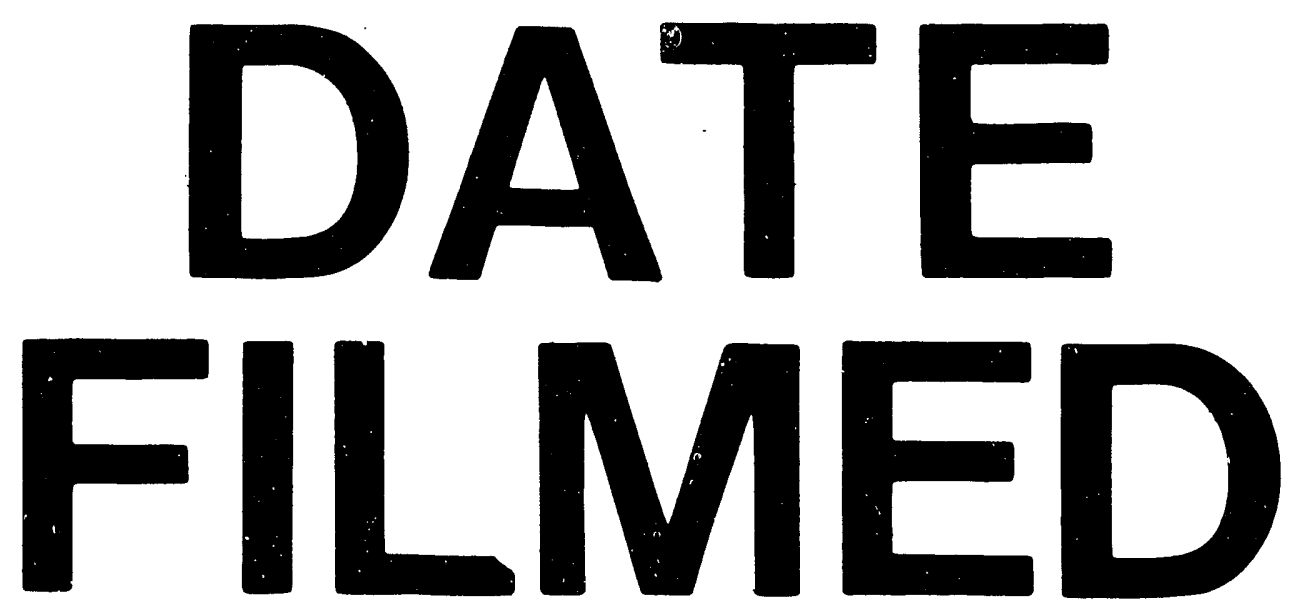

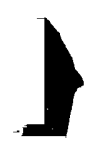

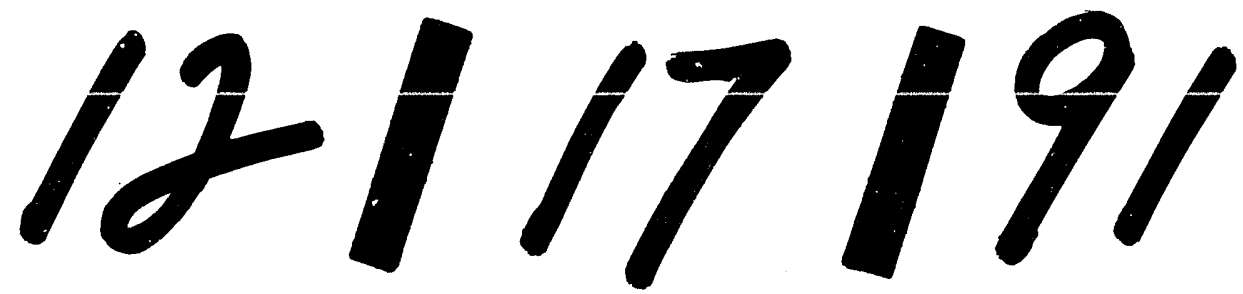




$$
-
$$

